Syntax Fusion : Jurnal Nasional Indonesia

p-ISSN: -

e-ISSN : 2775-4440

Vol. 1, No. 3, Maret 2021

\title{
AN ANALYSIS OF TEACHERS AND STUDENTS' PERCEPTION OF ONLINE READING AT INTEGRATED ISLAMIC ELEMENTARY SCHOOL
}

\author{
Cepy Misbakhul Qolby and Iswandini Agustin \\ English Language Teaching Department, Universitas Panca Sakti Bekasi \\ E-mail: cepy.misbakhul@gmail.com and_diniiswan@gmail.com
}

\begin{abstract}
This research purposes to analyze, how the teachers ' perceptions and students' perceptions of online reading in English learning. The explanation in this research is about the elements that influence online reading, the benefits of using online reading in class, and how online reading may help in the learning process, especially in reading. The questionnaire consists of fifteen statements and each statement has four alternative responses from one to four: agree, strongly agree, disagree, and strongly disagree. The questionnaire was distributed using Google Forms, and then the respondents were interviewed using WhatsApp. The results of the research indicate that teachers and the students show positive responses towards online reading. The teachers and the students perceived that online reading is ease than conventional reading. According to the research, there are benefits, including the ability for the teachers and students are to quickly find a reading topic by searching keywords, the ability for online reading to encourage students' independent learning attitudes, and students' increased interest in technology-based learning. There is one disadvantage: online reading is to be limited by the devices and tools accessible.
\end{abstract}

Keywords: Online Reading, Teachers' Perceptions, Students' Perceptions

\section{Introduction}

English has four major skills to be learned. There are listening, speaking, writing, and reading skills. Reading skill is needed by the learners to improve their ability to speak English fluently. Reading skill is required for students to pass both local and national written English examinations. Thus, teaching reading should begin in elementary school and continue through higher education. According to Kennedy (1981:5), reading is the ability of an individual that recognize that visual form to associate the form with the sound or meaning acquired in the past, and, understand on the past experience, and understand, and interpret is 
meaning.

Reading is frequently seen as a difficult skill among students. Students are unable to achieve reading success, which is the most important aspect of reading comprehension, especially in English. Reading is a language skill that has been integrated into the English lesson curriculum. Reading is essential for students who would like to expand their knowledge. Teachers require a strategy that is appropriate for the students while teaching reading. So they can hold the learning purposes. Anthony (1963) in Fauziati (2009:15) defines the method as "an overall plan for the orderly presentation of language material, no part of which contradicts, and all of which is based upon the selected approach".

In reading classes, teachers might use a variety of models. One of the models is online reading. In its development, the online reading technique can be used for the reading lesson. The Covid-19 pandemic, which affects all aspects of school activities, reinforces this technique. Learning and teaching must be carried out entirely online. They require an internet connection to carry out their learning activities and may do learning activities from a distance.

Nowadays, reading is not only about the printed text such as reading on paper in books, magazines, newspapers, journals but also reading can be done online or called online reading. Moreover, In today's technological world, online reading is essential. People may use their mobile phones, computers, iPads, laptops, and other devices to access the internet at any time and from anywhere.

Because of the Covid-19 pandemic strikes all over the world, SDIT Tahta Syajar is one of formal education in Bekasi city that also applies online learning in all elements of education implementation, especially reading in part of English lessons. Even if there is an internet network, the condition is still unable to cover online media. The costs are also an obstacle because many aspects of teachers' and students' welfare are still far from the expectations, clearly can't afford it when they utilize their internet limit to satisfy their online media requirements. However, teachers in Indonesia do not completely understand the use of technology, as indicated by teachers who were born in the 1970s. Their use of online media is limited because of information technology limitations.

Furthermore, internet networks do not reach all locations. Not all educational institutions, including elementary and secondary schools, have access to the internet. Even if an internet network exists, the situation is insufficient to cover online media. Costs are also a constraint because many elements of teachers' and students' welfare are still going short of expectations, and they clearly can't afford to utilize their internet quota to cover their online media needs. There is a dilemma in the use of internet media, but on the other hand, teachers' and students' financial skills and abilities have not developed in the same direction.

Coiro (2003) preceded the concept of online reading as about online literacy. They highlighted that literacy appears different challenges in the era of technology. They also discusses three types of texts that the readers may face on the internet: non- 
linear texts, multiple-media texts, and interactive texts. The differences between printed texts and online texts are hold in the format. Online text is manifested into hypertext and connected with links, icons, headings, and graphics.

Perception is the process of interpreting what we see and hear. The interpretation of sensory information requires greater degrees of cognitive perception. These sensory stimuli are processed based on our knowledge of the world, society, expectations, and even the individuals with whom we are conversing at the time. Simple sensory experiences take on new meaning as a result of these factors (Solso, Maclin \& Maclin, 2007).

As a result, the research will find to achieve its objectives, and the topic which is covered in this article will be described in the following questions:

1. How is the teachers' perception of online reading in English learning?

2. How are students' perceptions of online reading in English learning?

\section{Method}

The purpose of this research was to understand how teachers and students felt about their online reading learning. Reading is done online with the help of media and network-connected devices. This research was conducted by using a survey design, and as a result, the questioner was created as the research's instrument in addition to the researcher. The respondents of this research were 2 teachers and 51 students of sixth grade at Integrated Islamic Elementary School of Tahta Syajar. Researchers are interested in learning more about whether teachers and students think online reading is beneficial or disadvantageous.

The researcher employed descriptive qualitative research with the procedure as follows:

1. The data were collected from the source.

2. Analyzed the data from the source.

3. And concluded from the result analysis.

The data were collected by questionnaire. It was adapted from a previous research performed by (Sudijuno:2003) and (2010:195). It revealed the teachers' and students' perceptions of their online reading. And also according to Arikunto (2010:195), the questionnaire is split into different kinds, which are:

1. An open questionnaire that allows respondents to react in their own words.

2. A closed questionnaire is one in which the answer has already been supplied and the respondents are just required to choose a choice.

The questionnaire includes fifteen items with four possible replies ranging from one to four: agree, strongly agree, disagree, and strongly disagree. The researcher also interviewed several respondents as a sample to get the reason for their answers in their sentences. The researcher adopted the Miles, Hubarman, and Saldana (2014) theory to analyze the data, which suggests that data analysis consists of three procedures: data reduction, data display, and conclusion.

Two classes were chosen as the sample, then the respondents were given a 
questionnaire to complete their understanding of online reading. Google Form is the online media to distribute the questionnaire due to the global pandemic of the covid- 19 . The researcher also explains how to answer the questionnaire. To confirm that all participants understood the questionnaire, respondents can ask questions about it via WhatsApp chat.

After the participants completed the questionnaire, the researcher conducted an interview with the teachers and several students as the sample through WhatsApp chat before analyzing the data. The data were analyzed by the researcher from the questionnaire which on Google Form responses. As a result, the replies were expressed as a percentage and the reasons of their answer, which the researcher used to summarize the respondents' reaction to the questionnaire.

The researcher chose triangulation to check the validity of the data. According to Sugiyono (2006), triangulation is an useful technique for checking data validity. It may be understood as a data collecting technique that combines data from multiple data collection techniques with existing data. In this research, triangulation was utilized to combine information from both the students' and the teacher's sides. It also combines data collection methods. It also combines data collecting techniques such as documentation and interviews.

\section{Results And Discussion}

Based on the answer of the teachers' and students' respondents, it can be analyzed from statement 1 until 15 then it is categorized by three parts of perceptions for giving easier analysis, the first is effectiveness, the second is enthusiasm, and the third is devices and tools.

A. The effectiveness of online reading

a. Teachers' Perception

Table 1 . The percentage of effectiveness of teacher's perceptions

\section{No \\ The statements of perceptions \\ Percentage}

\begin{tabular}{llcc} 
& & Agree & Disagree \\
\hline 1 & The process of reading is easier with online reading & $100 \%$ & - \\
2 & $\begin{array}{l}\text { The reading process is more fun with online reading } \\
3\end{array}$ & $100 \%$ & - \\
$\quad \begin{array}{l}\text { Online reading makes the reading process more effective in } \\
\text { achieving learning objectives }\end{array}$ & $100 \%$ & - \\
4 & $\begin{array}{l}\text { Online reading can increase students' interest in reading } \\
5\end{array}$ & $100 \%$ & - \\
& $\begin{array}{l}\text { Online reading can improve students' understanding of } \\
\text { learning }\end{array}$ & - & $100 \%$ \\
\hline & Total & & $100 \%$
\end{tabular}

The process of reading is easier with online reading. The teachers have the perception that they agree with this statement. They think that students can more easily 
find a reading topic by searching for the keywords.

The reading process is more fun with online reading. The teachers have the perception that they agree with this statement. They think that students are more interested in technology-based learning.

Online reading makes the reading process more effective in achieving learning objectives. The teachers have the perception that they agree with this statement. They think that students can more easily find the topic they want.

Online reading can increase students' interest in reading. The teachers have the perception that they agree with this statement. They think that the students are more interested in technology-based learning.

Online reading can improve students' understanding of learning. The teachers have the perception that they disagree with this statement. They think that students will be difficult to mark the text to find the information.

b. Students' Perception

The process of reading is easier with online reading. Most students have the perception that they agree with this statement.

Student 1 : Because online reading is using a cellphone or laptop, so I can get material and assignments from the teachers, I open my cellphone and I can work on it and send it to the teachers.

Student 2: Because English online reading is easy, for example, if we want to search for the meaning of the question, we can translate directly from the dictionary and don't need to open the dictionary again, flipping through to see the meaning.

Student 3: Because reading through online learning is easier with other various application methods available on mobile phones.

Reading process is more fun with online reading. Most students have the perception that they agree with this statement.

Student 1: Because reading it (online), we can use your cellphone, so it's more relaxed and fun.

Student 2: Because it's easier and faster to do it online so it's fun to finish quickly.

Student 3: Because it will complete the task given by the teachers quickly, so it will be more achieved.

Online reading makes the reading process more effective in achieving learning objectives. Most students have the perception that they agree with this statement.

Student 1: Because online reading, I'm more focused on paying attention to the material given by the teachers.

Student 2: Because students will pay more attention to the learning task, and be faster in doing the learning task.

Student 3: Because students will complete the tasks given by the teachers quickly, they will achieve the learning objectives. 
Online reading can increase students' interest in reading. Most students have the perception that they disagree with this statement.

Student 1: Because sometimes online reading is boring and makes us dizzy for a long time.

Student 2: Because students will pay more attention to what material has been given online so students are afraid that they will miss the next material.

Student 3: Because I am often tempted to open other applications.

Online reading can improve students' understanding in learning. Most students have the perception that they disagree with this statement.

Student 1: Because sometimes reading through online is not clear.

Student 2: Because online reading does not make it easier for students to receive material.

Student 3: Because sometimes online reading is hard to understand.

Table 2. The percentage of effectiveness of students' perceptions

\begin{tabular}{llcc} 
& Agree & Disagree \\
\hline 1 & The process of reading is easier with online reading & $89 \%$ & $11 \%$ \\
2 & $\begin{array}{l}\text { The reading process is more fun with online reading } \\
3\end{array}$ & $69 \%$ & $31 \%$ \\
$\quad \begin{array}{l}\text { Online reading makes the reading process more effective in } \\
\text { achieving learning objectives }\end{array}$ & $89 \%$ & $11 \%$ \\
4 & $\begin{array}{l}\text { Online reading can increase students' interest in reading } \\
5\end{array}$ & $59 \%$ & $41 \%$ \\
$\quad \begin{array}{l}\text { Online reading can improve students' understanding of } \\
\text { learning }\end{array}$ & $82 \%$ & $11 \%$ \\
\hline Total & & $100 \%$
\end{tabular}

In order to answer research question, the finding from the teachers' and students' questionnaire with the reason and the students' questionnaire is shown in table 2 .

After analyzing the data, the researcher found significant elements that lead to the effectiveness of online reading. The majority of respondents have the same opinion about the effectiveness of online reading. According to the research, statements 1 to 5 have the highest level of strongly agree and agree which are categorized as agree. According to research, the teachers and the majority of students agree that online reading offers positive things in their reading activities.

B. The enthusiasm of online reading

a. Teachers' Perception

Table 3. The percentage of the enthusiasm of teachers' perceptions

No The statements of perceptions

Percentage 


\begin{tabular}{llcc} 
& & Agree & Disagree \\
\hline 1 & Online reading can foster students' motivation in reading & $100 \%$ & - \\
2 & $\begin{array}{l}\text { Online reading makes it easy to facilitate students in } \\
\text { submitting assignments of reading comprehension }\end{array}$ & $100 \%$ & - \\
3 & $\begin{array}{l}\text { Online reading can foster students' independent reading } \\
\text { comprehension attitudes }\end{array}$ & $100 \%$ & - \\
4 & Online reading can save time in the learning process & $100 \%$ & - \\
5 & Online reading can foster students' motivation in reading & $100 \%$ & - \\
\hline & Total & \multicolumn{2}{c}{$100 \%$}
\end{tabular}

Online reading can foster students' motivation in reading. The teachers have the perception that they agree with this statement. They think that students are more interested in technology-based learning.

Online reading makes it easy to facilitate students in submitting assignments of reading comprehension. The teachers have the perception that they agree with this statement. They think students can find more easily a reading topic by searching for the keywords.

Online reading can foster students' independent reading comprehension attitudes. The teachers have the perception that they agree with this statement. They think that students can find the meaning of words/sentences independently online.

Online reading can save time in the learning process. Teachers have the perception that they agree with this statement. They think that students can more easily find a reading topic by searching for the keywords.

Online reading makes it easy for students or teachers to communicate and interact anytime and anywhere. The teachers have the perception that they agree with this statement. They think that students and teachers can communicate and interact directly through technology devices.

b. Students' Perception

Online reading can foster students' motivation in reading. Most students have the perception that they are disagree with this statement.

Student 1: Because online reading only depends on cellphones or laptops, so I'm a lot bored and try to open social media.

Student 2: Because online reading makes students less enthusiastic in working on the material so it does not motivate students.

Student 3: Because students are more enthusiastic about reading directly (luring), so there is no motivation to read online.

Online reading makes it easy to facilitate students in submit assignments of reading comprehension. Most students have the perception that they disagree with this statement.

Student 1: Because all applications are not easy to use, for example, Google Classroom, I'm not good at sending assignments on it.

Student 2: Because online reading doesn't make it easy to submit assignments and it's 
still confusing at reading comprehension.

Student 3: Because in the process of submitting reading assignments, the internet network is sometimes lost so we repeat to submit assignments.

Online reading can foster students' independent reading comprehension attitudes. Most students have the perception that they agree with this statement.

Student 1: Because reading in this model is done at home, so I will be independent in studying and doing assignments].

Student 2: Because the students are working on the material by themselves, they can't possibly ask their parents to do it].

Student 3: students do the material themselves without asking for help from their parents who do not understand technology.

Online reading can save times in the learning process. Most students have the perception that they agree with this statement.

Student 1: Because the reading process saves time without taking notes first.

Student 2: Because material online reading is faster, only one day so it saves time.

Student 3: Because I don't need to take notes by hand, so it saves more time.

Online reading makes it easy for students or teachers to communicate and interact anytime and anywhere. Most students have the perception that they agree with this statement

Student 1: Because online reading can be done anytime and anywhere.

Student 2: students and teachers have their own groups so online reading is easier.

Student 3: Because it's easy to do and the material can be downloaded easily.

Table 4. The percentage of the enthusiasm of student's perceptions

\section{No The statements of perceptions}

Percentage

\begin{tabular}{llcc} 
& Agree & Disagree \\
\hline 1 & $\begin{array}{l}\text { Online reading can foster students' motivation in reading } \\
2\end{array}$ & $47 \%$ & $53 \%$ \\
& $\begin{array}{l}\text { Online reading makes it easy to facilitate students in } \\
\text { submitting assignments of reading comprehension }\end{array}$ & $49 \%$ & $51 \%$ \\
3 & $\begin{array}{l}\text { Online reading can foster students' independent reading } \\
\text { comprehension attitudes }\end{array}$ & $80 \%$ & $20 \%$ \\
4 & $\begin{array}{l}\text { Online reading can save time in the learning process } \\
5\end{array}$ & $94 \%$ & $6 \%$ \\
\hline & Online reading can foster students' motivation in reading & $86 \%$ & $14 \%$ \\
\hline
\end{tabular}

In order to answer research questions, the finding from the teachers' and students' questionnaire with the reason and the students' questionnaire is shown in table 4.

After analyzing the data, the researcher found significant elements that lead to the enthusiasm of online reading. The majority of respondents have the same opinion about the enthusiastic of online reading. According to the research, statements 1 to 5 have the highest level of strongly agree and agree which are categorized as agree even though 
there are negative perceptions at motivating and submit assignment. According to research, the teachers and the majority of students agree that online reading offers positive things in their reading activities.

C. The devices and tools of online reading

a. Teachers' Perception

Table 5. The percentage of using the devices and tools of teachers' perceptions

No

The statements of perceptions

Percentage

\begin{tabular}{llcc} 
& Agree & Disagree \\
\hline $1 \quad \begin{array}{l}\text { Students or teachers have problems in implementing online } \\
\text { reading because of limited mobile phone facilities, limited } \\
\text { internet packages, and poor signal problems }\end{array}$ & $100 \%$ & - \\
2 & $\begin{array}{l}\text { Online reading is difficult to do because of the lack of } \\
\text { students' understanding of the use of online applications } \\
\text { Online reading is a part of learning English that utilizes } \\
\text { internet networks as a learning tool }\end{array}$ & $100 \%$ & - \\
$4 \quad \begin{array}{l}\text { Online reading is wasteful of internet data } \\
\text { Based on the technological sophistication of the modern era, } \\
\text { online reading can continue to be developed }\end{array}$ & $100 \%$ & - \\
\hline
\end{tabular}

Total

$100 \%$

Students or teachers have problems in implementing online reading because of limited mobile phone facilities, limited internet packages, and poor signal problems. The teachers have the perception that they agree with this statement. They think that not all students/schools have technology devices support.

Online reading is difficult to do because of the lack of students' understanding of the use of online applications. The teachers have the perception that they agree with this statement. They think that not all students/schools have technology devices support.

Online reading is a part of learning English that utilizes internet networks as a learning tool. The teachers have the perception that they agree with this statement. They think that the implementation needs internet network.

Online reading is wasteful of internet data. The teachers have the perception that they disagree with this statement. They think that online reading requires fewer internet data usage.

Based on the technological sophistication of the modern era, online reading can continue to be developed. The teachers have the perception that they agree with this statement. They think that online reading is part of technology-based learning which supports students to study.

b. Students' Perception 
Students or teachers have problems in implementing online reading because of limited mobile phone facilities, limited internet packages, and poor signal problems. Most students have the perception that they agree with this statement.

Student 1: Because not all of students have cellphones, for example, some of my friends don't have cellphones, so it's difficult for them to do it].

Student 2: Because not all students have cell phones and not all students can afford internet packages.

Student 3: Because not all of students have cell phones and internet packages.

Online reading is difficult to do because of the lack of students' understanding in using online applications. Most students have the perception that they agree with this statement.

Student 1: Because online reading has been done lately, I don't know how to use the application, so it's difficult to use it online.

Student 2: Because there are still many students who don't understand to use handphones.

Student 3: Because there are students who don't understand about handphones and applications on handphone.

Online reading is a part of learning English that utilize internet networks as a learning tool. Most students have the perception that they are agree with this statement.

Student 1: Because it is not only a handphone, an internet network is needed to operate the online application.

Student 2: Because the internet network is used to download materials.

Student 3: Because the internet network is used for important things so it is not wasted.

Online reading is wasteful of internet data. Most students have the perception that they are strongly agree with this statement.

Student 1: Because it requires internet data to open an application, download a file with an image.

Student 2: Because a lot of material are images so that it consumes internet data.

Student 3: Because some students don't focus on online reading, so they waste the internet data.

Based on the technological sophistication of the modern era, online reading can continue to be developed. Most students have the perception that they agree with this statement.

Student 1: Because I really enjoy online reading.

Student 2: Because online reading makes it easier for me.

Student 3: Because I do not want to read online that makes me dizzy.

Table 6. The percentage of using the devices and tools of students' perceptions

No

The statements of perceptions

Percentage

Agree Disagree

1 Students or teachers have problems in implementing online $\quad 90 \% \quad 10 \%$ 


\begin{tabular}{llll}
\hline & $\begin{array}{l}\text { reading because of limited mobile phone facilities, limited } \\
\text { internet packages, and poor signal problems }\end{array}$ & & \\
2 & $\begin{array}{l}\text { Online reading is difficult to do because of the lack of } \\
\text { students' understanding of the use of online applications }\end{array}$ & $89 \%$ & $11 \%$ \\
3 & $\begin{array}{l}\text { Online reading is a part of learning English that utilizes } \\
\text { internet networks as a learning tool }\end{array}$ & $90 \%$ & $10 \%$ \\
4 & $\begin{array}{l}\text { Online reading is wasteful of internet data } \\
\text { Based on the technological sophistication of the modern era, } \\
\text { online reading can continue to be developed }\end{array}$ & $90 \%$ & $10 \%$ \\
\hline & Total & 100\% \\
\hline
\end{tabular}

In order to answer research questions, the finding from the teachers' and students' questionnaire with the reason and the students' questionnaire which is shown in table 6.

After analyzing the data, the researcher found significant elements that lead to constraints in online reading. The majority of respondents have the same opinion that they need proper devices and tools for online reading. According to the research, statements 1 to 4 have the highest level of strongly agree and agree which are categorized as agree. It means that online reading has negative perceptions to utilize devices and tools. But based on the technological developments, they agree that online reading can be continued.

\section{Conclusion}

In this research, it is claimed that the teachers' and students' perspectives have many similarities, while there are some differences. The teachers have a complimentary opinion on online reading, stating that the reading process is simplified online. Online reading improves the effectiveness of the reading process in accomplishing learning objectives. Students more easily find the reading topic by searching the keywords. Students are more interested in technology-based learning. On the other hand, students will find it difficult to mark the text to discover the material, and online reading is blocked by a lack of devices because of not all students have the devices properly, but the teachers believe that online reading can be enhanced.

Students agree with the teachers' statement who have a positive perception of online reading, believing that the process of reading is easier with online. It is indicated by the average percentage of effectiveness in table 2 of $79 \%$ for the agreed statement. On the enthusiasm of online reading, some students believe they are unmotivated and find it difficult to complete assignments, as indicated by the 52 percent of students who disagree with the statements in table 4 , but they believe they agree in order to facilitate communication and time saving, with an average of 87 percent of students agreeing. In terms of enthusiasm, students tend to have positive perceptions. Limited devices, lack of using applications, internet networks usage, wasteful of internet data, and technology developments were identified to be difficulties in the implementation of online reading. 
Cepy Misbakhul Qolby and Iswandini Agustin

According to the research, there are benefits, including the ability for the teachers and students are to quickly find a reading topic by searching keywords, the ability for online reading to encourage students' independent learning attitudes, and students' increased interest in technology-based learning. There is one disadvantage: online reading is to be limited by the devices and tools accessible. However, based on the teachers' and students' perceptions, online reading can still be improved. 
An Analysis Of Teachers And Students' Perception Of Online Reading At Integrated Islamic Elementary School

\section{Bibliografi}

Arikunto. (2010). Prosedur PenelitianSuatu Pendekatan Praktik. Jakarta: Rineka Cipta.

Bentley, Y., Selassie, H., \& Theygunshi, A. (2012). Design and evaluation of studentfocused eLearning. Electronic Journal of E-Learning, 10(1), pp.1-12. doi : https://doi.org/10.1007/s10648- 013-9243-1

Coiro, J. (2003). Reading Comprehension on the Internet: Expanding our understanding of reading comprehension to encompass new literacies. The Reading Teacher, 56, p.458-464.

Coren, S., \& Girgus, J. S. (1980). Principles of perceptual organization and spatial distortion-The Gestalt illusions. Journal of Experimental Psychology: Human Perception and Performance, 6, p. 404-412.

Fauziati, Endang. (2009). Introduction to Methods and Approaches in Second or Foreign Language Teaching. Surakarta: Era Pustaka.

Fauziati, Endang. (2010). Teaching English as a Foreign Language. Surakarta: Era Pustaka.

Fiske, S. T., \& Taylor, S. E. (1991). Social Cognition. New York: McGraw-Hill.

Irwanto. (2002). Psikologi Umum. Jakarta: Gramedia Pustaka Utama.

Kennedy, Eddie C. (1981). Methods in Teaching Developmental Reading $2^{\text {nd }}$ Edition. England: Peacock Publitheyrs, Inc.

Lin, E., \& Lin, C. H. (2015). The Effect of Teacher- Student Interaction on Students ' Learning Achievement in Online Tutoring Environment International Journal of Technical Research and Application, E-ISSN: 2320-8163, 22(22), p.19-22.

Manalu, Benni H. (2019. Digital Reading: A Case Study at the English Education Department of Universitas Kristen Indonesia. Journal of English Teaching. 5 (3), pp.191-196. doi: http://dx.doi.org/10.33541/jet.v5i3.1312

Miles, M.B, Huberman,A.M, dan Saldana,J. (2014). Qualitative Data Analysis, A Methods Sourcebook, Edition 3. USA: Sage Publications. Terjemahan Tjetjep Rohindi Rohidi, UI-Press. 
Cepy Misbakhul Qolby and Iswandini Agustin

Ozturk, O. (2017). The Relationsship between Autonomy Perception and the Reading Comprehension Achievement of English Language Learners. Journal of Education Research, p.15-28.

Solso, Maclin, Maclin. (2008). Psikologi Kognitif. edisi kedelapan. Jakarta: Erlangga.

Sudijono, Anas. (2003). Pengantar Evaluasi Pendidikan. Jakarta: Raja Grafindo Persada.

Sugiyono. (2006). Metode Penelitian Kuantitatif, Kualitatif dan R\&D. Bandung : Alfabeta.

Walgito, Bimo. (2004). Pengantar Psikologi. Yogyakarta: Andi Offset. 